\title{
ע Miesten parisuhteettomuuden yhteys hyvinvointiin
}

\begin{abstract}
Aikaisemmissa tutkimuksissa on todettu parisuhteen vaikuttavan elämänlaatuun erityisesti miehillä. Parisuhteettomuuden valinnaisuudesta ei juuri puhuta ja ydinperheolettama elää vahvana. Tässä tutkimuksessa selvitettiin, missä määrin miehet toivovat parisuhdetta ja miten parisuhteettomuus on yhteydessä miesten hyvinvointiin. Yksin eläviä mutta itselleen parisuhdetta toivovia miehiä verrattiin miehiin, jotka elävät yksin ilman parisuhdetoiveita ja parisuhteessa oleviin miehiin. Hyvinvointia tarkasteltiin kolmen eri ulottuvuuden avulla: onnellisuus, yksinäisyys ja psykosomaattiset oireet. Tutkimus tehtiin kvantitatiivisin menetelmin, ja se perustuu Väestöliiton ja Helsingin yliopiston keräämään FINSEX-aineistoon vuosilta 1992, 1999, 2007 ja 2015. Aineistossa on 2797 iältään 25-64-vuotiasta miestä. Heistä joka kuudes elää ilman parisuhdetta. Tästä joukosta enemmistö toivoo itselleen parisuhdetta. Parisuhdetta itselleen toivovat miehet kokivat muita parisuhteettomia enemmän yksinäisyyttä. Heillä oli myös enemmän ylirasittuneisuutta, ahdistuneisuutta ja jännittyneisyyttä sekä painajaisunia kuin niillä parisuhteettomilla miehillä, jotka eivät toivoneet parisuhdetta. Parisuhdetta itselleen toivovat eivät kuitenkaan olleet merkitsevästi onnettomampia kuin muut parisuhteettomat. Kaikista vertailuryhmistä parhaiten voivat parisuhteessa olevat miehet. Tutkimustulokset osoittavat, että varsinaisen parisuhdetilanteen lisäksi hyvinvointiin vaikuttaa merkittävästi myös omat toiveet tilanteen suhteen. Tulosten perusteella näyttää myös, että miesten parisuhde toiveiden taustalla voi olla enemmän yksinäisyyden kokemuksen lievittämiseen kuin onnellisuuden tavoitteluun liittyviä motiiveja.
\end{abstract}

\section{ASIASANAT: yksinäisyys, parisuhde, hyvinvointi, mies}

\section{ANU KINNUNEN, OSMO KONTULA}

\section{JOHDANTO}

Tutkimuksessa selvitetään ilman parisuhdetta elävien (single), jatkossa parisuhteettomien, hyvinvoinnin yhteyttä parisuhdetoiveisiin. Parisuhteettomuus jaetaan toivottuun eli yksilön toiveiden mukaiseen parisuhteettomuuteen ja ei-toivottuun parisuhteettomuuteen. Tutkimuksen aineisto tarjosi mahdollisuuden tarkastella hyvinvointia kolmella eri ulottuvuudella, yksinäisyyden, onnellisuuden ja psykosomaattisten oireiden perusteella.

Tässä tutkimuksessa tutkimuksen kohteeksi on rajattu vain miehet, koska viimeaikaisissa parisuhteettomien tutkimuksessa (1-5) on usein tutkittu ensisijaisesti naisia. Miehiin kohdistuvaa parisuhteettomien tutkimusta on huomattavasti vähemmän ja se kohdistuu usein yksinomaan homomiehiin (6-9). Erojen terveysvaikutuksia koskevien tutkimusten perusteella miehillä näyttäisi olevan naisia suurempi riski eron ja leskeytymisen aiheutuviin ongelmiin, kuten masennukseen ja kohonneeseen itsemurhariskiin (10-12).

\section{HYVINVOINTI}

Vielä kymmenen vuotta sitten pohjoismaisessa hyvinvointitutkimuksessa nähtiin hyvinvoinnin kytkeytyvän ihmisten käytössä oleviin resursseihin, kuten työhön, tuloihin, terveyteen ja asumiseen. Tutkimuksen keskiössä oli näiden resurssien sosioekonomisen kohdentumisen tarkastelu (13). Erityisesti viimeisten kymmenen vuoden aikana tutkimuksen painopiste on siirtynyt kokemukselliseen suuntaan. Koetun hyvinvoinnin käsite 
lähenee elämääntyytyväisyyttä ja onnellisuutta. Elämääntyytyväisyys- ja onnellisuustutkimukset tulevat hieman eri taustoista, mutta Suomen kaltaisessa hyvinvointivaltiossa niitä voidaan pitää jokseenkin synonyymeinä keskenään ja käyttää mittaamaan hyvinvoinnin kokemusta (13). Elämääntyytyäisyyttä mittaavat tutkimukset pohjaavat elämänlaadun (quality of life) näkökulmaan, jossa huomioidaan laajasti elämän eri osa-alueita. Onnellisuustutkimuksissa puolestaan keskitytään onnellisuuteen ensisijaisesti tunteena ja subjektiivisena kokemuksena. Terveyden ja hyvinvoinnin laitos seuraa Aikuisten terveys-, hyvinvointi- ja palvelututkimuksella (ATH) väestön ja eri väestöryhmien hyvinvoinnissa ja terveydessä tapahtuneita muutoksia. Koettua hyvinvointia mitataan siinä onnellisuuteen, elämänlaatuun, ihmissuhteisiin ja työhön tyytyväisyyteen liittyvillä kysymyksillä (14).

Anne Birgitta Pessin tutkimuksessa osallistujat nimesivät eniten onnellisuutta tuoviksi elementeiksi elämässään tärkeysjärjestyksessä perheen, terveyden, rakkauden, ystävät ja säännölliset tulot (15).

Sakari Kainulaisen tutkimuksissa on todettu parisuhdetilanteen olevan selvästi yhteydessä elämänlaatuun (16,17). Parisuhteessa elävien elämänlaatu oli parisuhteettomia korkeampi. Yksineläjien kohdalla miesten elämänlaatu oli naisia heikompi. Erityisen huono elämänlaatu oli tutkimuksen mukaan eronneilla ja naimattomilla miehillä (16). Ihmissuhteet, muilta tuleva kunnioitus ja rakkaus vaikuttavat tutkimustulosten mukaan vahvasti elämänlaatuun, vaikka talouden vaikutus otetaankin huomioon $(17,18)$. Kainulainen käytti tutkimuksissaan yleisesti käytettyä ja hyvinvointia laaja-alaisesti kartoittavaa Personal Well Being -indeksiä (19), joka arvioi ihmisten tyytyväisyyttä kahdeksalla elämän osaalueella: elintaso, terveydentila, saavutukset elämässä, henkilökohtaiset ihmissuhteet, oma turvallisuus, kuuluminen ryhmiin, turvattu tulevaisuus sekä hengellisyys.

Suomalaisessa iäkkäitä koskevassa tutkimuksissa on todettu kumppanittomuuden ja sosiaalisten verkostojen puutteen lisäävän turvattomuutta, mikä heikentää elämänlaatua (20). Näyttääkin siltä, että hyvinvointivaltioissa, missä perustarpeet on tyydytetty läheisten ihmissuhteiden merkitys hyvinvoinnille korostuu ja varallisuuden merkitys vähenee $(13,21)$. Onnellisuus tutkimukset eri maiden välillä ovat hieman hankalasti vertailtavissa, koska odotukset sille, mitä yhteiskunnan tulisi tarjota muuttuvat elintason noustessa. Onnellisuus on siis jossain määrin suhteellista toisin kuin resurssipohjaisesti määritelty hyvinvointi.

Toimivat ihmissuhteet lisäävät elämänlaatua ja vastaavasti monissa eri tutkimuksissa on todettu yksinäisyyden alentavan elämänlaatua $(22,23)$. Yksinäisyyttä on määritelty eri tavoin. Tutkittaessa yksinäisyyttä voidaan asiaa kysyä suoraan tai käyttää kattavaa monikohtaista, esimerkiksi UCLAn, yksinäisyysmittaristoa (24). Yhteistä useille määritelmille kuitenkin on, että yksinäisyys nähdään sosiaalisten suhteiden puutteena, subjektiivisena kokemuksena ja luonteeltaan epämiellyttävä (25). Yksin oleminen ei siis välttämättä tarkoita yksinäisyyttä. Elisa Tiilikainen puhuu yksinäisyyden elämänkulullisesta luonteesta (26). Yksinäisyys saattaa liittyä johonkin elämänvaiheeseen tai olla koko elämää varjostava kokemus. Tiilikaisen tutkimukseen osallistuneilla iäkkäillä yksinäisillä ilmeni rakkauden ja kiintymyksen kaipuuta, yhteen kuulumattomuuden tunnetta sekä arvottomuuden ja tarpeettomuuden kokemuksia (27).

Margaret Wetherel ja Jill Reynolds (3) ovat tutkineet parisuhteettomien identiteetin määrittymistä. Neljä keskeisintä tulkintaa, joita tutkimukseen osallistuneet naiset käyttivät apunaan määrittäessään omaa parisuhteettomuuttaan, olivat: parisuhteettomuus henkilökohtaisena vajeena, parisuhteettomuus sosiaalisena kuulumattomuutena, parisuhteettomuus itsenäisyytenä ja valintana sekä parisuhteettomuus itsensä toteuttamisena ja saavutuksena. Näistä edellä mainituista kaksi ensimmäistä näyttäytyivät negatiivisina ja kaksi viimeistä korostuneen idealisoituneina.

Myös englantilaisen Shelley Budgeonin (28) tutkimuksessa parisuhteettomanidentiteettiä määritettäessä toistui ulkopuolisuuden tarinat ja oletusarvoisen normatiivisen parisuhteen "toisella puolella" oleminen. Parisuhteettomuus tai sinkkuus on jo määritelmältään jonkin puutetta ja siinä mielessä negatiivinen "puutteen identiteetti”. Vanessa May (29) toteaa, että kaikkein henkilökohtaisimpiakin kokemuksiamme muokkaa sosiokulttuurinen konteksti, jossa kyseinen kokemus ilmenee. Parisuhteettomuuden valinta on kontrastissa yleisen diskurssin kanssa, jossa pari- 
suhteettomuus nähdään joko henkilökohtaisena epäonnistumisena tai muista valinnoista maksettuna hintana (1). Mikäli parisuhteettomuus nähdään ainoastaan kielteisesti, tuetaan samalla normatiivista perinnettä ja parisuhteen kulttuurista erikoisasemaa ainoana oikeana tapana elää (30).

Omaan parisuhteettomuuteen positiivisesti suhtautuminen edellyttää, että kykenee luomaan itselle positiivisen identiteetin. Elämän valinnat edustavat sitä mitä olemme, identiteettiämme ja viestiä muille siitä, millainen ihminen olemme (1). Myös parisuhteettomuudesta puhuttaessa keskeinen teema on valinnaisuus. Onko parisuhteettomuus itse valittua vai onko kyseessä ei-toivottu tilanne? Naisten keskuudessa tehdyssä tutkimuksessa (5) oman parisuhteettomuuden selitykset vaihtelivat paljon henkilökohtaisista ominaisuuksista ulkopuolisiin olosuhteisiin. Valinnan käsite ei ole kuitenkaan täysin yksiselitteinen, sillä parisuhteettomuus voidaan nähdä epäsopivaa kumppania parempana vaihtoehtona. Avioeron jälkeen saatetaan uuden suhteen solmimista pitää julkisena osoituksena ja todisteena sitä, että erosta on selvitty onnistuneesti (31).

Aikaisemman tutkimuksen pohjalta tiedämme onnellisuuteen usein liitettävän keskeisinä tekijöinä perhe, rakkaus ja ystävät. Yksin elävien määrän jatkuvasti kasvaessa on keskeistä ymmärtää, miten parisuhteettomuuden valitseminen tai toivotun kumppanin puuttuminen heijastuu hyvinvointiin.

\section{TUTKIMUKSEN TARKOITUS JA TUTKIMUSKYSYMYKSET}

Tässä tutkimuksessa selvitettiin parisuhteettomien miesten koettua hyvinvointia. Erityisesti tarkasteltiin tutkittavien tilannetta parisuhteettomuuden valinnan näkökulmasta.

Tarkastelimme tutkimuksessa seuraavia kysymyksiä:

- Esiintyykö parisuhdetilanteesta riippuvia hyvinvointieroja miesten keskuudessa, kuten kirjallisuudessa on esitetty?

- Eroaako parisuhdetta toivovien miesten hyvinvointi muista parisuhteettomista miehistä?

\section{TUTKIMUKSEN AINEISTO JA MENETELMÄT}

\section{AINEISTON KUVAUS}

Tutkimusaineisto on kerätty osana suomalaisten seksuaalisuutta, asenteita ja käyttäytymistä kartoittava FINSEX-tutkimushanketta (32-35). Tutkimuksen poikkileikkausaineisto on kerätty vuosina 1992, 1999, 2007 ja 2015. Aineiston on kerännyt Väestöliiton Väestöntutkimuslaitos (1999, 2007 ja 2015) ja Helsingin Yliopiston kansanterveystieteen laitos (1992). Aineisto kattaa koko maan aikuisväestön ja perustuu väestön keskusrekisteristä poimitulle otannalle. Vastaukset on kerätty käyntihaastatteluina vuonna 1992 ja postikyselyllä vuosina 1999, 2007 ja 2015. Vuonna 2015 oli mahdollista vastata myös sähköisesti. Vastauslomake sisälsi 127 kysymystä, joista osassa oli myös alakohtia. Kysymykset ovat pysyneet pääpiirteissään samoina vuodesta toiseen. Nyt tehdyssä tutkimuksessa hyödynnettiin vain osaa vastauksista.

Mukaan valitut vastaajat olivat 25-64-vuotiaita miehiä. Nuoremmilla katsottiin parisuhteettomuuden kuuluvan ikävaiheeseen ja vanhemmilla ikääntymisen vaikuttavan ratkaisevasti parisuhdetoiveisiin. Tutkimukseen osallistui 2797 miestä. Vastaajien keski-ikä oli 44,1 vuotta. Mukana oli 425 parisuhteetonta miestä. Miesten seksuaalinen suuntautuminen ei ollut tässä tutkimuksessa tarkastelun kohteena.

Kyselytutkimuksen vastausprosentit olivat keräysvuosina 75,9 \%, 45,8 \%, 43,4 \% ja 36,0 \%. Vastausprosentti on laskenut huomattavasti vuodesta 1992 vuoteen 2015, mikä johtuu ensisijaisesti keräystavan muuttumisesta käyntihaastattelusta postikyselyyn. Otoskokoa on vastaavasti nostettu, ja mukana olevista vastauksista $24 \%$ oli vuodelta 2015. Parisuhteettomia miehiä tutkittaessa on kuitenkin syytä muistaa, että kokonaisväestöön perustuvilla kyselytutkimuksilla ei yleensä tavoiteta kaikkein huono-osaisimpia (36). Huono-osaisia miehiä sisältävissä väestöryhmissä voi olettaa ilman parisuhdetta elävien osuuden olevan korkeampi kuin muussa väestössä. On myös mahdollista, että parisuhteettomat ovat vastanneet tutkimukseen parisuhteellisia harvemmin. 
Taulukko 1. Aineiston jakautuminen vuoden ja parisuhdetilanteen mukaan n=2657 FINSEX 1992-2015.

\begin{tabular}{|c|c|c|c|c|c|c|c|c|c|c|}
\hline & \multicolumn{2}{|c|}{$1992 n=815$} & \multicolumn{2}{|c|}{$1999 n=400$} & \multicolumn{2}{|c|}{$2007 n=792$} & \multicolumn{2}{|c|}{$2015 n=650$} & \multicolumn{2}{|c|}{ yhteensä $n=2657$} \\
\hline & $\mathrm{n}$ & $\%$ & $\mathrm{n}$ & $\%$ & $\mathrm{n}$ & $\%$ & $\mathrm{n}$ & $\%$ & $\mathrm{n}$ & $\%$ \\
\hline $\begin{array}{l}\text { toivoo } \\
\text { parisuhdetta }\end{array}$ & 54 & 6,6 & 38 & 9,5 & 69 & 8,7 & 70 & 10,8 & 230 & 8,7 \\
\hline $\begin{array}{l}\text { ei toivo } \\
\text { parisuhdetta }\end{array}$ & 49 & 6 & 16 & 4 & 50 & 6,3 & 44 & 6,8 & 259 & 6,0 \\
\hline parisuhteessa & 712 & 87,4 & 346 & 86,5 & 673 & 85 & 536 & 82,5 & 2267 & 85,3 \\
\hline
\end{tabular}

Khiin neliö -testi, $\mathrm{p}=0,06$

\section{MITTARIT}

Alkuperäiset kysymykset, niiden vastausvaihtoehdot ja vastausten uudelleenluokittelu on esitetty taulukossa 2. Taustamuuttujina on käytetty ikää ja tuloja. Varsinaiset tutkimusmuuttujat olivat parisuhdetilanne, onnellisuus, yksinäisyys ja psykosomaattiset oireet. Parisuhdetilannetta kysyttiin neljällä kysymyksellä. Aineiston analyysia varten parisuhdetilannetta kartoittavien kysymyksien vastaukset luokiteltiin uudelleen. Todellinen parisuhdetilanne ja parhaana pidetty elämäntyyli yhdistettiin uudeksi kolmiluokkaiseksi muuttujaksi (katso taulukko 2.) seuraavasti: 1) ilman parisuhdetta olevat, jotka eivät toivo parisuhdetta (ei ole naimisissa, ei asu avoliitossa, ei ole muuta suhdetta eikä toivo parisuhdetta) 2) ilman parisuhdetta olevat, jotka toivovat parisuhdetta (ei ole naimisissa, ei asu avoliitossa, ei ole muuta suhdetta, toivoo parisuhdetta) 3) tällä hetkellä parisuhteessa olevat (on naimisissa tai on avoliitossa tai on muu suhde). Kaikki parisuhteessa olevat otettiin mukaan luokkaan 3 riippumatta heidän parisuhdetoiveistaan.

Yksinäisyyttä kysyttiin aineistossa elämäntilanteeseen viittaavalla kysymyksellä, samoin onnellisuutta (taulukko 2). FINSEX-kyselyyn sisältyi viimeisen kuukauden aikana esiintyneiden psykosomaattisten oireiden esiintyvyyttä ja esiintymisen tiheyttä kuvaava indeksi (35). Psykosomaattisista oireista otettiin mukaan tarkasteluun lähes kaikki aineistossa mukana olevat oireet eli unettomuus, päänsärky, jännittyneisyys/ahdistuneisuus, ylirasittuneisuus, väsymys, huimaus, painajaisunet ja ilman ruumiillista ponnistelua esiintyvä hikoilu tai kuumotus.

\section{MENETELMÄT}

Aineistoa analysoitiin frekvensseinä, prosentteina, keskiarvoina ja keskihajontoina. Muuttujien välisiä yhteyksiä tarkasteltiin ristiintaulukoinnin ja Khiin neliö -testin sekä binäärisen logistisen regression avulla.

Parisuhteettomuuden yleisyyttä tarkasteltiin ikäluokittain prosenttijakaumina. Erojen tilastollista merkitsevyyttä tutkittiin ristiintaulukoinnilla ja Khiin neliö -testillä. Psykosomaattisia oireita tarkasteltiin vertaamalla parisuhdetta toivovien oireilua niihin miehiin, jotka eivät toivo itselleen parisuhdetta ja parisuhteessa oleviin miehiin.

Parisuhdetilanteen, onnellisuuden, yksinäisyyden, tulojen ja iän välistä yhteyttä selvitettiin edelleen binäärisellä logistisella regressioanalyysillä. Tarkastelu tehtiin kahdessa erillisessä vertailussa. Ensin verrattiin parisuhdetta itselleen toivovia parisuhteettomiin, jotka eivät toivo itselleen parisuhdetta (vertailu 1) ja sitten parisuhteessa eläviin (vertailu 2). Parisuhdetta itselleen toivovat ovat viiteryhmä molemmissa tarkasteluissa. Malleille laskettiin vakioimattomat ja vakioidut regressiokertoimet. Vakioimattomassa mallissa muuttujia on tarkasteltu yksi kerrallaan ja vakioidussa mallissa kaikki selittävät muuttujat, eli onnellisuus, yksinäisyys, ikä ja tulot, on otettu mukaan malliin samanaikaisesti. Tuloksissa esitetään jokaiselle muuttujan luokalle $\mathrm{n}$, ristitulosuhde (OR), $95 \%$ luottamusväli (lv) sekä p-arvo ja mallin selitysaste Nagelkerke $\mathrm{R}^{2}$. Tilastollisesti merkitsevänä pidettiin arvoa $\mathrm{p}<0,05$ (37). Analyysiin käytettiin IMB SPSS 23 -ohjelmistoa. 
Taulukko 2. Kysymykset aineistossa, vastausluokat ja uudelleenluokittelu.

Kysymys aineistossa

Taustamuuttujat

Minä vuonna olette syntynyt?

syntymävuosi

Kuinka suuret ovat tulonne kuukaudessa, 1-10, keräyskerroittain vaihtuva kun verot on vähennetty? raja-arvot vuonna 2015

$1=$ alle $500 €, 10=$ yli $2050 €$
Uudelleenluokittelu

ikä vuosina

$1-4=1,5-6=2,7-8=3$, $9-10=4$

\section{Parisuhdetilanne}

Oletko tällä hetkellä?

Asutteko tällä hetkellä avoliitossa?

Onko Teillä muu parisuhde, mutta ette asu kuitenkaan yhdessä?

Asuuko Teidän kanssanne vakituisesti omia tai kumppaninne lapsia?

Mitä seuraavista elämäntyyleistä pidätte itsellenne parhaimpana elämänne tässä vaiheessa?
1 = naimaton, 2 = naimisissa asuen yhdessä puolison kanssa, 3 = naimisissa asuen erillään, 4 = eronnut, 5 = leski.

\section{kyllä/ei}

1 = ei ole, 2 = kyllä, yksi, 3 = on, kaksi tai useampia.

kyllä/ei

1 = En halua sukupuolikokemuksia tai solmia sukupuolisuhdetta, 2 = En halua vakituisia kumppaneita, tilapäisiä kylläkin, kun siltä tuntuu, 3 = Haluan muutamia vakituisia kumppaneita, 4 = Haluan yhden vakituisen kumppanin, mutta en halua asua hänen kanssaan, $5=$ Haluan asua kumppanini kanssa (ilman avioliittoa) mutta haluan lisäksi muita suhteita, $6=$ Haluan asua kumppanini kanssa (ilman avioliittoa) enkä haluan lisäksi muita suhteita, $7=$ Haluan olla naimisissa, mutta haluan tämän lisäksi muita suhteita, $8=$ Haluan olla naimisissa, enkä halua muita suhteita, 9 = En osaa sanoa mikä olisi paras.
$1=$ ei naimisissa $(1,4 \& 5)$

$2=$ naimisissa $(2 \& 3)$

kyllä/ei

$1=$ en toivo vakituista parisuhdetta $(1,2 \& 9)$ $2=$ toivon vakituista parisuhdetta $(3,4,5,6,7 \& 8)$

Jos olette ollut sellaisessa tilanteessa, $\quad 1=$ erittäin vaikeaa, $2=$ melko vaikeaa, että olette kaivannut sukupuoli-

3 = vaikeaa eikä helppoa, $4=$ melko kumppania, onko kumppanin löytyminen helppoa, 5 = täysin helppoa, 6 = en ole ollut Teille: kaivannut sukupuolikumppania

Yksinäisyys, onnellisuus ja psykosomaattiset oireet

Millainen on elämäntilanteenne juuri nyt?

1-4, 1 = hyvin yksinäinen, 4 = ei lainkaan yksinäinen.

Millaisena pidätte elämäänne juuri nyt?

1 = hyvin onnellista,

5 = hyvin onnetonta

Onko teillä viimeisen kuukauden aikana esiintynyt a) unettomuutta,

1 = ei juuri lainkaan

b) päänsärkyä, c) jännittyneisyyttä tai ahdistuneisuutta d) ylirasittuneisuutta,

e) yleistä väsymystä tai heikkouden tunnetta, f) huimausta, g) painajaisunia,

2 = joskus

h) käsien vapinaa, i) kuumotusta tai hikoilua ilman ruumiillista ponnistelua? 
Taulukko 3. Miesten parisuhdetoiveet ikäryhmittäin, FINSEX 2002-2015 n = 2657 .

\begin{tabular}{|c|c|c|c|c|c|c|c|c|c|c|}
\hline \multirow[t]{2}{*}{ ikäryhmä } & \multicolumn{2}{|c|}{$25-34 n=697$} & \multicolumn{2}{|c|}{$35-44 n=680$} & \multicolumn{2}{|c|}{$45-54 n=671$} & \multicolumn{2}{|c|}{$55-64 n=609$} & \multicolumn{2}{|c|}{ yhteensä $\mathrm{n}=2657$} \\
\hline & $\mathrm{n}$ & $\%$ & $\mathrm{n}$ & $\%$ & $\mathrm{n}$ & $\%$ & $\mathrm{n}$ & $\%$ & $\mathrm{n}$ & $\%$ \\
\hline toivoo parisuhdetta & 84 & 12,1 & 56 & 8,3 & 42 & 6,3 & 49 & 5,5 & 231 & 8,7 \\
\hline ei toivo parisuhdetta & 58 & 8,3 & 29 & 4,3 & 38 & 5,7 & 34 & 5,4 & 159 & 6,0 \\
\hline parisuhteessa & 555 & 79,6 & 595 & 87,5 & 591 & 88,1 & 526 & 86,5 & 2267 & 85,3 \\
\hline
\end{tabular}

\section{TULOKSET}

\section{MIESTEN PARISUHDETILANNE}

Tutkimukseen osallistuneista miehistä 2657 kertoi parisuhdetoiveistaan. $15 \%$ ilmoitti elävänsä tällä hetkellä ilman parisuhdetta. Ilman parisuhdetta elävistä kolme viidennestä $(59 \%)$ toivoi jonkinlaista vakituista parisuhdetta. Yksi neljännes $(25 \%)$ ei toivonut itselleen vakituista parisuhdetta. Loput $16 \%$ eivät osanneet sanoa, millainen elämäntyyli olisi heille paras. He eivät siis kyenneet sanomaan haluaisivatko he olla parisuhteessa ja jos, niin minkälaisessa. Parisuhdetta toivovat olivat myös olleet muita useammin tilanteessa, jossa olivat kokeneet parisuhteen löytämisen vaikeaksi.

\section{PARISUHTEEN TOIVOMINEN IÄN MUKAAN}

Taulukossa 3 on esitetty miesten parisuhteettomuuden esiintyvyys ikäryhmittäin. Parisuhteen toivominen oli parisuhteettomilla miehillä yleistä. Kaikissa ikäryhmissä yli puolet parisuhteettomista toivoi elävänsä vakituisessa parisuhteessa. Voimakkainta parisuhteen toivominen oli 35-44-vuotiaiden ikäryhmässä, jossa kaksi kolmesta $(66 \%)$ parisuhteettomasta miehestä toivoi itselleen kumppania (Taulukko 3). Parisuhteettomia oli eniten nuorimman ikäryhmän (25-34-vuotiaiden) keskuudessa: heistä viidennes $(20 \%)$ eli ilman vakituista kumppania. Parisuhteessa oleminen oli yleisintä 45-54-vuotiaiden ikäryhmissä. 55-64-vuotiaiden ryhmässä toiveet parisuhteesta laskivat ja kumppania kaipaamattomien yksineläjien osuus oli korkein yli 60-vuotiailla, heistä puolet (49\%) piti itsenäistä elämää ilman kumppania hyvänä ratkaisuna. Erot eri luokkien välillä olivat tilastollisesti merkitseviä, $\mathrm{p}<0,001$.

\section{PARISUHTEETTOMUUS JA HYVINVOINTITEKIJÄT}

Parisuhdetta itselleen toivovien miesten psykosomaattista oirehdintaa verrattiin yhtältä miehiin, jotka eivät toivo parisuhdetta ja toisaalta parisuhteessa oleviin miehiin (Kuvio 1). Ne miehet, jotka toivoivat tällä hetkellä itselleen vakituista parisuhdetta, kokivat muita parisuhteettomia enemmän seuraavia oireita: painajaisunia $(\mathrm{p}=0,002)$, ylirasittuneisuutta $(\mathrm{p}=0,040)$; jännittyneisyyttä ja ahdistuneisuutta $(\mathrm{p}=0,034)$.

Parisuhteessa olevat miehet voivat analyysin tulosten perusteella paremmin kuin parisuhteettomat miehet. He olivat ainoastaan ylirasittuneempia kuin miehet, jotka eivät toivo parisuhdetta. Ylirasittuneisuus saattoi johtua niin sanotuista ruuhkavuosista, sillä ylirasittuneisuus oli korkeinta kaikista miehistä niillä, jotka asuivat yhdessä joko omien tai kumppanin lasten kanssa $(\mathrm{p}=0,036)$.

Päänsärky osoittautui ristiintaulukoinneissa muuttujista ainoaksi, jolla ei ollut tilastollisesti merkitsevää yhteyttä parisuhdetilanteeseen.

Logistisella regressioanalyysillä tarkasteltiin parisuhdetilanteen yhteyttä onnellisuuteen, yksinäisyyteen, ikään ja tuloihin. Tulokset on esitetty taulukossa 4.

Ensimmäisessä vakioimattomassa vertailussa pyrittiin selittämään parisuhdetta toivovien ryhmään kuulumista (vertailu 1, parisuhdetta toivovat miehet vs. miehet, jotka eivät toivoneet parisuhdetta). Tarkasteltaessa muuttujia yksi kerrallaan havaittiin, että yksinäisyys ja tulot nousivat tärkeimmiksi selittäjiksi. Kun malli vakioitiin ja kaikki muuttujat (onnellisuus, yksinäisyys, ikä ja tulot) otettiin kerralla mukaan, saatiin mallin selitysasteeksi $\mathrm{R}^{2}=0,045$. Vakioidussa mallissa ainoaksi tilastollisesti merkitseväksi selittäjäksi nousi tulot, tuloluokat 7 ja 8 , $\mathrm{p}=0,009$. Parisuhteen toivominen korostuu tuloluokkien ääripäissä pieni- ja suurituloisissa. 


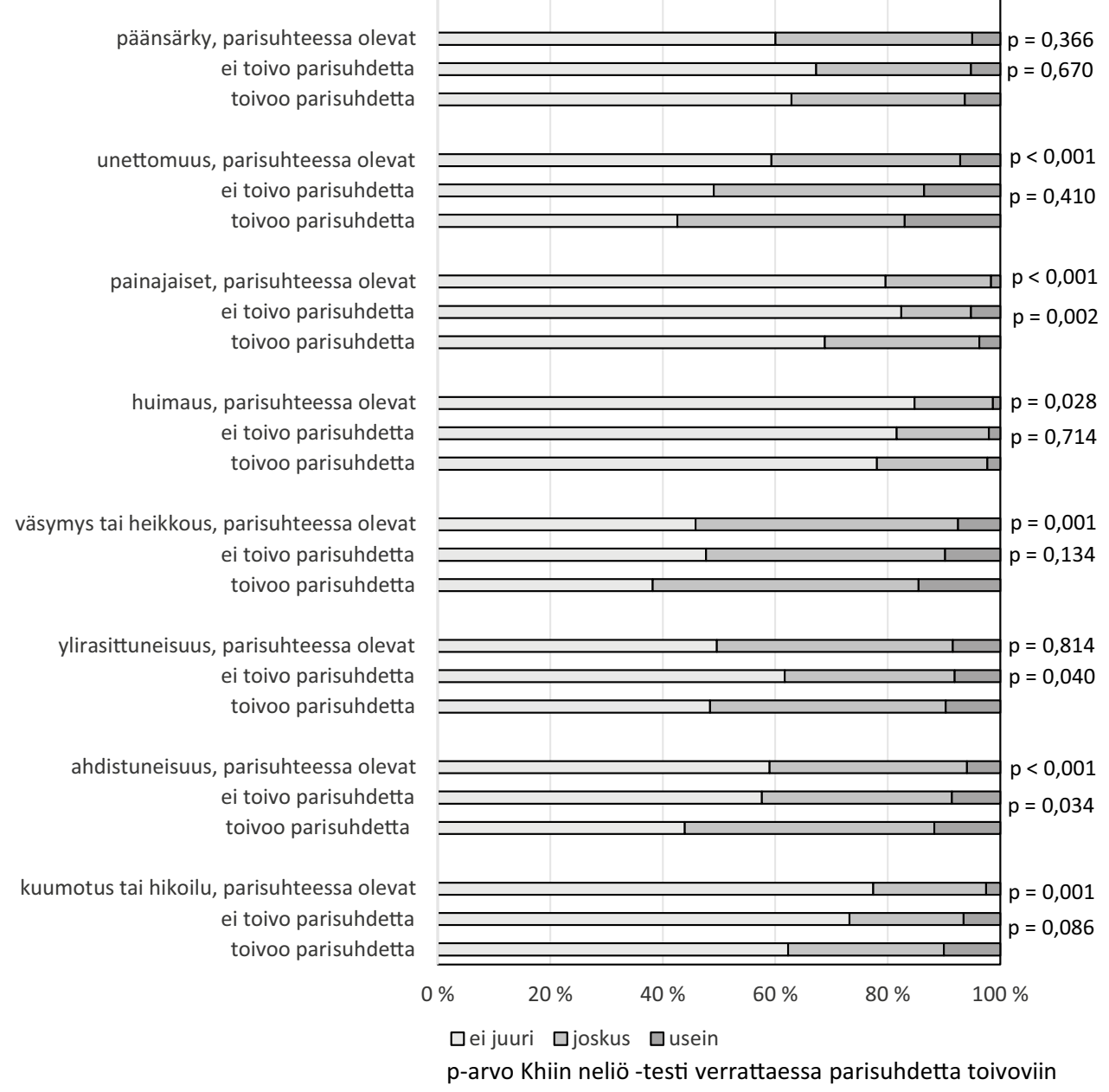

Kuvio 1. Miesten raportoimien oireiden esiintyvyys parisuhdetilanteen mukaan, FINSEX 1992-2015 $\mathrm{n}=2657$

Toisessa vakioimattomassa vertailussa (vertailu 2, parisuhdetta toivovat miehet vs. parisuhteessa olevat miehet) parisuhteen toivominen oli yhteydessä kaikkiin tarkasteltuihin muuttujiin. Korkeimmat vetosuhteet ja selitysasteet olivat yksinäisyydellä $\left(\mathrm{R}^{2}=0,32, \mathrm{p}<0,001\right)$, tuloilla $\left(\mathrm{R}^{2}=0,065, \mathrm{p}<0,001\right)$ ja onnellisuudella $\left(\mathrm{R}^{2}=0,141, \mathrm{p}<0,001\right)$. Kun malli vakioitiin ja kaikki muuttujat otettiin kerralla mukaan, saatiin mallin selitysasteeksi $\mathrm{R}^{2}=0,37$. Mallia vakioitaessa kaikki selittävät muuttujat säilyivät tilastollisesti merkittävinä, onnellisuus ( $p=0,001)$, yksinäisyys $(\mathrm{p}<0,001)$, ikä $(\mathrm{p}<0,001)$ ja tulot $(\mathrm{p}<0,001)$.
Koska tutkimuksen aineisto on kerätty 23 vuoden aikana nähtiin tarpeelliseksi tarkastella myös aineiston yhtenäisyyttä. Eri keräyspisteistä saatuja aineistoja verrattiin toisiinsa muuttuja kerrallaan. Tehdyn ristiintaulukoinnin avulla oli havaittavissa, että vuonna 1992 monen tekijän kohdalla on voitu hieman paremmin kuin vuosina 1999, 2007 ja 2015. Erojen tilastollinen merkittävyys väheni, mikäli tarkastelu rajoitettiin ainoastaan parisuhdetta itselleen toivoviin miehiin. Koko ajanjaksolla yhtenäisenä muutossuuntana näkyi miesten ylirasittuneisuuden jatkuva väheneminen ja samalla myös vuosi vuodelta lisääntyvä onnellisuus. Aineistossa näkyy myös, että 
(6) -

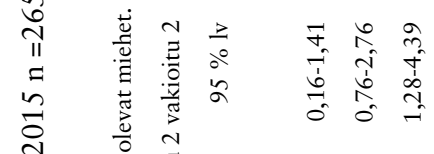

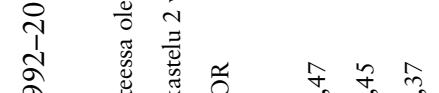

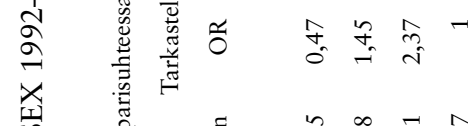

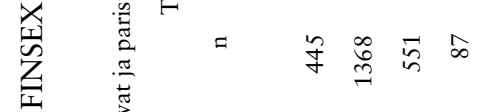

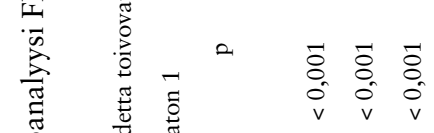

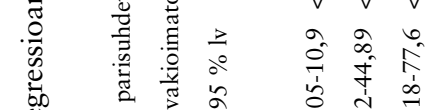

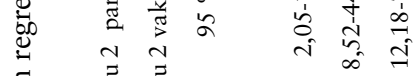

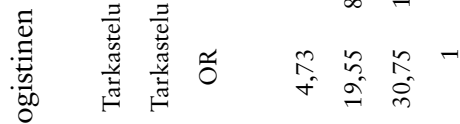

站

西

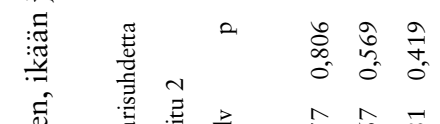

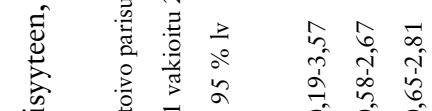

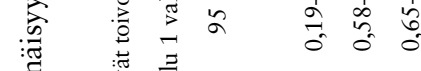

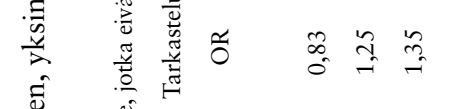

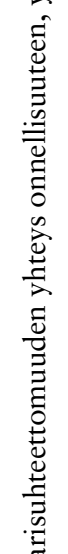

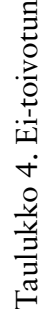

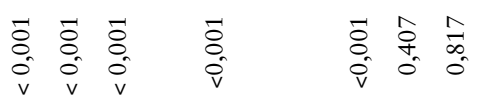

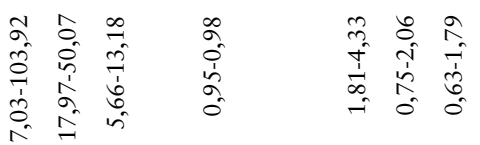

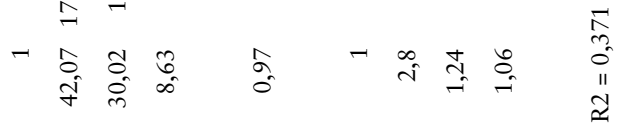

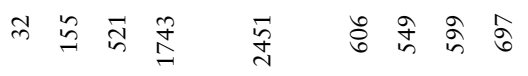

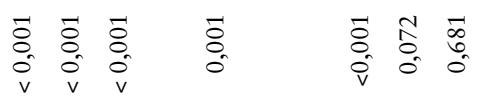

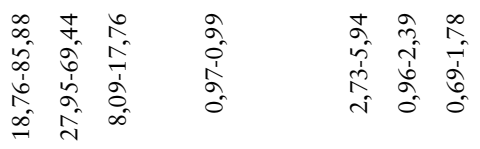

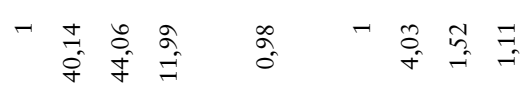

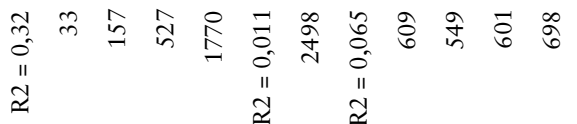

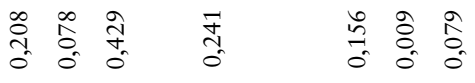

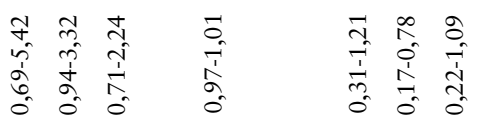

-

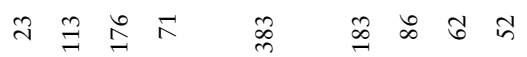

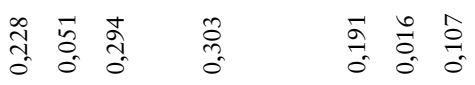

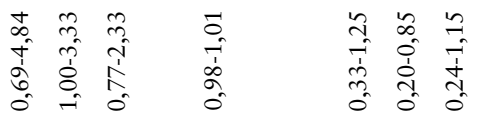

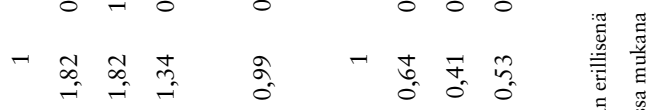

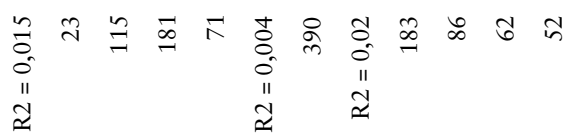

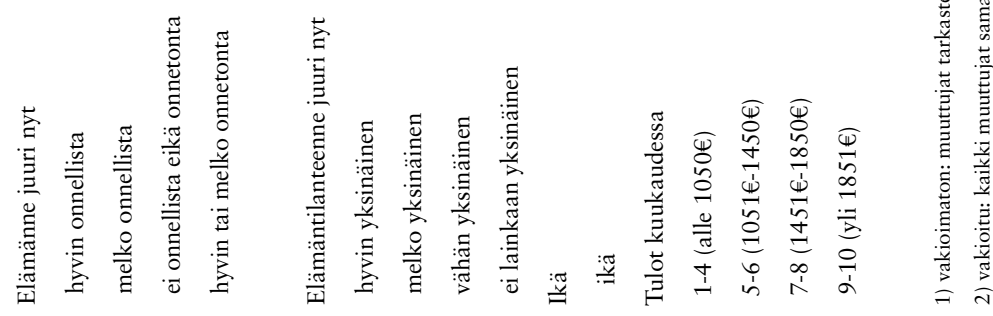


vastausprosentin laskiessa vuosina 2007 ja 2015 on samalla myös vastaajien sijoittuminen aikaisempaa korkeampiin tuloluokkiin korostunut. Parisuhteettomien alaryhmien tarkastelu ei ole vuositasolla luetettavasti mahdollista aineiston suppeudesta johtuen.

\section{POHDINTA}

Parisuhteettomuus oli yleisintä nuorimmassa 25-34-vuotiaiden ikäluokassa. Vaikka yksineläminen onkin yleistynyt (38), parisuhteettomuuteen tyytyväisten osuus laskee nopeasti iän myötä. Iäkkäimpien ryhmässä parisuhteettomuuteen tyytyväisyys kuitenkin kohoaa. Tähän voi ehkä olla syynä yksinelämiseen tottuminen tai oman kumppanin menetyksen hyväksyminen. Tutkimuksessa yli puolet parisuhteettomista toivoi parisuhdetta kaikissa tutkimuksen ikäryhmissä. Tämä tulos on yhteneväinen parisuhteettomien naisten tarinoita Britanniassa tutkineen Simpsonin tutkimustuloksien kanssa (1). Hän toteaa, että vaikka parisuhteettomien toimijuus omassa elämässään on vahvistunut, ei pitkittynyt parisuhteettomuus siltikään esiintynyt hänen tutkimien naisten tarinoissa toivottuna tilanteena.

Nyt tehty tutkimus jaotteli parisuhteettomat suhteen toiveen perusteella. Tuloksissa yksinäisyys nousi esille. Yksinäisyyttä esiintyi enemmän parisuhdetta toivovilla kuin omaan parisuhteettomuuteensa tyytyväisillä. Onnellisuuden kohdalla vastaavaa eroa ei näiden ryhmien välillä kuitenkaan löytynyt. Tämän perusteella näyttää, että kumppanin toivomisen taustalla voi olla enemmän halu pois epämiellyttävänä koetusta yksinäisyydestä kuin puuttuvan onnellisuuden tavoittelu. Aikaisemmissa tutkimuksissa on käynyt ilmi, että etenkin miehille kumppanin olemassaolo onkin tärkeä yksinäisyyden kokemuksen vähentäjä (39-41), ja että parisuhde toimii usein linkkinä myös muihin sosiaalisiin suhteisiin (42).

Psykosomaattisia oireita tarkasteltaessa havaittiin parisuhdetta itselleen toivovilla miehillä esiintyvän merkitsevästi muita parisuhteettomia enemmän painajaisia, ylirasittuneisuutta sekä jännittyneisyyttä tai ahdistuneisuutta. Kirjallisuudessa on esitetty, että päiväaikaan koettu stressi voi olla hyvin yhteydessä yöllisiin painajaisiin (43). Painajaisille on ominaista voimakkaat negatiiviset tunteet, kuten yleisimpänä pelko, suru tai viha (44). Mikäli omaan parisuhteettomuuteen ei liittynyt toteutumattomia toiveita, olivat oireet vähäisempiä. Parisuhdetta toivovat olivat myös muita parisuhteettomia useammin kokeneet parisuhteen löytymisen vaikeaksi tai erittäin vaikeaksi. Niiden miesten joukossa, jotka eivät toivoneet tällä hetkellä parisuhdetta oli myös miehiä, jotka eivät olleet koskaan olleet siinä tilanteessa, että olisivat toivoneet parisuhdetta. Heitä voidaan pitää vakiintuneina yksineläjinä.

Oman elämäntilanteen hyväksynnällä näyttäisi siis olevan yhteys psykosomaattiseen oireiluun. Avun vastaanottaminen oman elämäntilanteen hyväksymiseen, esimerkiksi terapeutilta, voi auttaa hyväksymään parisuhteettomuuden, näkemään sen omana valintana tai muuten tarkoituksellisena tässä hetkessä. Hostetlerin (6) miehï käsittelevässä tutkimuksessa on saatu samansuuntaisia tuloksia. Siinä selvitettiin parisuhteettomien miesten hyvinvoinnin yhteyttä parisuhteettomuuteen sopeutumiseen ja käytettävissä olevaan sosiaalisen tuen määrään. Tuki lisäsi hyvinvointia, mutta vastaava hyvinvoinnin taso oli saavutettavissa myös muulla tavoin tilanteeseen sopeutumisella. Parisuhteettomana hyvin voiminen ei siis edellytä välttämättä sosiaalista tukea vaan oman näköisen elämän elämistä.

Sopeutuminen parisuhteettomuuteen todennäköisesti riippuu pitkälti valinnan ja kontrollin kokemuksesta (6). Aikaisemmissa tutkimuksissa on todettu, että naimisissa oleviin miehiin verrattuna parisuhteettomilla miehillä on vähemmän itsensä hyväksyntää, positiivisia ihmissuhteita ja he kokevat elämän vähemmän tarkoitukselliseksi (45). Miehillä parisuhteen puuttumiseen liittyy tilastojen perusteella myös heikompi asema työmarkkinoilla ja epävarmempi toimeentulo (46). Nämä tekijät voivat osaltaan selittää parisuhteettomien oireita, tosin eivät eroa suhdetta toivovien ja tilanteeseensa tyytyväisten välillä.

Miksi parisuhdetta kuitenkin niin vahvasti toivotaan? Arvotutkimuksissa suomalaisten on todettu arvostavan erityisen paljon parisuhdetta (47). Suomalaisessa 1051 vastausta kattavassa onnellisuustutkimuksessa onnellisuuden viisi tärkeintä lähdettä olivat perhe, terveys, rakkaus, ystävät ja vakaat tulot (15). Avioliitto on instituutiona menettänyt merkitystään, ja avioliiton vaalimisen sijaan painotetaan yhä enemmän 
parisuhteen hoitamista (48). Samalla parisuhteiden laadulle on asetettu aiempaa suurempia vaatimuksia $(47,49)$. Äärimuotoa tällaisesta siirtymästä edustaa Giddensin ajatus ulkopuolisista sidoksista (suku, perinteet, talous) vapaista puhtaista suhteista, jotka rakentuvat täysin yksilöllisten valintojen varaan (50). Parisuhteen toivomisen taustalla voi olla myös toive vilkkaammasta seksielämästä. Tutkimustulosten mukaan vakituisessa parisuhteessa elävillä keski-ikäisillä on parisuhteettomia enemmän seksuaalista kanssakäymistä (51).

Historiallisesti ilman parisuhdetta elävät ovat vähemmistö ja parisuhteessa olevat nauttivat erilaisia etuuksia niin sosiaalisella, taloudellisella kuin symbolisellakin tasolla (52-54). Ilmiö löytyy myös suomalaisesta yhteiskunnasta, esimerkiksi etuuspolitiikasta (55). Parisuhteettomana yleisesti hyväksytystä normista poikkeaminen asettaa haasteita positiivisen identiteetin luomiselle. Osa syistä toivoa parisuhdetta voi siis olla yhteiskunnan odotusten aiheuttamia.

Tutkimuksen jokaisella kolmella ulottuvuudella tarkasteltaessa ilmeni, että parisuhteessa olevat voivat parisuhteettomia paremmin. Parisuhteen vaikutusta koettuun hyvinvointiin on tutkittu aiemminkin ja nyt saadut tulokset ovat linjassa aikaisempien kanssa. Saman suuntaisia tuloksia on saatu myös fyysiseen terveyteen ja yksinäisyyden kokemukseen liittyen (23) (56) (57). Aina parisuhteessa olemisen hyvistä vaikutuksista kerrottaessa on syytä kuitenkin muistuttaa, että ne joilla on huonoja kokemuksia parisuhteessa todennäköisemmin eroavat ja eron aiheuttamat mahdolliset oireet näkyvät siten parisuhteettomien tilastoissa. Eronneet voivat eron jälkeen muita parisuhteettomia huonom$\min (58)$.

Tämän tutkimuksen vahvuuksia ovat aineisto, joka on kerätty osana laajempaa FINSEX-tutkimusprojektia. Vastauksiin ei ole näin ollen voi- nut vaikuttaa tieto, että ollaan tekemässä juuri parisuhteettomuutta koskevaa tutkimusta.

Tutkimukseen liittyy myös heikkouksia. Aineisto on kerätty 23 vuoden ajalta ja tarvittavan osallistujamäärän varmistamiseksi eri keräysajankohtien aineistot on yhdistetty. Aineisto ei ole kuitenkaan käyttäydy täysin yhtenäisesti eri vuosina, mikä osaltaan heikentää tulosten yleistettävyyttä. Vuoden 1992 aineiston mukana oleminen tuo tuloksiin optimistisuutta miesten hyvinvoinnin suhteen. Kysymys "Mitä elämän tyyliä pidätte itsellenne parhaimpana tässä elämänvaiheessa?" oli kysymys numeroltaan 126/127 eli aivan lomakkeen lopussa. Tämä osaltaan supisti aineistoa, koska kaikista vastaajista ei ollut käytettävissä analyysin kannalta keskeisiä tietoja. Parisuhteettomien osuus oli vastanneissa sen verran pieni, ettei vuositason tarkasteluja parisuhteettomien alaryhmien (toivoo suhdetta/ei toivo suhdetta) kesken voitu tehdä.

Tutkimus tuo uutta tärkeää tietoa ei-toivotun parisuhteettomuuden yhteydestä miesten hyvinvointiin. Parisuhteettomia ei tule käsitellä yhtenäisenä ryhmänä. Parisuhteettomuuden valinnaisuus ja hyväksyntä ovat merkittäviä tekijöitä hyvinvoinnin taustalla. Olettamus parisuhdetoiveen keskeisyydestä johtaa riskiin parisuhteettomuuden tulkinnasta puutteen identiteettinä. Ei-toivottu parisuhteettomuus on uhka hyvinvoinnille. Siitä kärsiviä voidaan auttaa tukemalla heitä oman näköisen elämän luomisessa.

\section{KIITOKSET}

Tutkimusta on rahoittanut Oskar Öflundin säätiö.

\section{KIRJOITTAJIEN KONTRIBUUTIOT:}

AK osallistui tutkimuksen suunnitteluun ja toteutukseen sekä oli vastuussa artikkelin kirjoittamisesta. OK osallistui artikkelin kirjoittamiseen. Tekijät vastaavat koko artikkelista yhdessä. 
This article investigates to what extent men strive for couple relationships and how singleness relates to well-being. Three dimensions, viz. happiness, loneliness and psychosomatic symptoms, served as indicators of well-being. Our data is from the National Study of Human Relations, Sexual Attitudes and Lifestyles in Finland (FINSEX), 1992, 1999, 2007 and 2015. This data covers 2797 men aged 25-64. Of these, one in six lives without an intimate relationship; most strive for a couple relationship. In the quantitative analysis, we compared singles striving for a couple re- lationship, singles without a strong wish for such a relationship, and men in couple relationships. Single men striving for a couple relationship reported higher levels of loneliness than other singles. They also had more nightmares, anxiety and overstraining than the other two groups. The results show that well-being is not only connected with the relationship status but also with the possible contradiction between the actual and the desired relationship status.

Keywords: loneliness, singleness, well-being, men

Saapunut 30.1.2017

Hyväksytty 23.5.2017

\section{LÄHTEET}

1. Simpson R. Singleness and self-identity: The significance of partnership status in the narratives of never-married women. J Soc Pers Relt 2016;33:385-400. https://doi.org/10.1177/0265407515611884

2. Byrne A. Developing a Sociological Model for Researching Women's Self and Social Identities. European Journal of Women's Studies 2003;10:443-64. https://doi.org/10.1177/13505068030104010

3. Reynolds J, Wetherell M. The Discursive Climate of Singleness: The Consequences for Women's Negotiation of a Single Identity. Fem Psychol 2003;13:489-510. https://doi.org/10.1177/09593535030134014

4. Mäkinen A. Oikeesti aikuiset: Puheenvuoroja yksineläjänaisen normaaliudesta, hyväksyttävyydestä ja aikuisuudesta. Tampere: Tampereen yliopisto; 2008.

5. Reynolds J, Wetherell M, Taylor S. Choice and chance: negotiating agency in narratives of singleness. Sociol Rev 2007;55:331-51. https://doi.org/10.1111/j.1467954X.2007.00708.x

6. Hostetler AJ. Singlehood and Subjective WellBeing among Mature Gay Men: The Impact of Family, Friends, and of Being "Single by Choice". Journal of GLBT Family Studies 2012;8:361-84. https://doi.org/10.1080/1550428X.2012.705621

7. Hostetler AJ. Single by Choice? Assessing and Understanding Voluntary Singlehood Among Mature Gay Men. J Homosex 2009;56:499-531. https://doi.org/10.1080/00918360902821486

8. Sharp EA, Elliott C, Zvonkovic A. Young, Single Gay Men's Commitment and Long-Term Partner Preferences. Journal of GLBT Family Studies 2011;7:349-67.

https://doi.org/10.1080/1550428X.2011.592965
9. Suen YT. Older Single Gay Men's Body Talk: Resisting and Rigidifying the Aging Discourse in the Gay Community. J Homosex 2017(64).

10. Yip PSF, Yousuf S, Chan CH, ym. The roles of culture and gender in the relationship between divorce and suicide risk: A meta-analysis. Soc Sci Med 2015;128:87-94. https://doi.org/10.1016/j.socscimed.2014.12.034

11. Stack S, Scourfield J. Recency of Divorce, Depression, and Suicide Risk. J Fam Issues 2015;36:695-715. https://doi.org/10.1177/0192513X13494824

12. Lee GR, DeMaris A. Widowhood, Gender, and Depression A Longitudinal Analysis. Res Aging 2007;29:56-72. https://doi.org/10.1177/0164027506294098

13. Saari J. Onnellisuuspolitiikka: Kohti sosiaalisesti kestävää Suomea. Jyväskylä: Kalevi Sorsa säätiö; 2012.

14. Kaikkonen R, Murto J, Pentala O, ym. Alueellisen terveys- ja hyvinvointitutkimuksen perustulokset 2010-2015. Luettu 2.12.2016. www.thl.fi/ath

15. Pessi A-B. What constitutes Experiences of Happineness and Good Life: Building a Novel Model on the Everyday Experiences. Kirjassa: Tissari H, Pessi AB, Salmela M (toim.) Happiness: Cognition, Experience, Language. Helsinki: Helsinki Collegium for Advanced Studies; 2008.

16. Kainulainen S. Yksinäisen elämänlaatu. Kirjassa: Saari, J (toim.) Yksinäisten Suomi. Helsinki: Gaudeamus; 2016.

17. Kainulainen S. Raha ja rakkaus hyvinvoinnin lähteinä. Yhteiskuntapolitiikka 2014;79:485-97.

18. Gillespie BJ, Lever J, Royce T, Frederick D. Gender and the Importance of Close Friendship for Life Satisfaction and Happiness. Conference Paper. American Sociological Association 2013;1-47. 
19. International Wellbeing Group. Personal Wellbeing Index: 5th Edition. Melbourne: Australian Centre on Quality of Life, Deakin University; 2013.

20. Savikko N, Routasalo P, Tilvis R, Pitkälä K. Ikääntyneiden turvattomuus ja sen yhteys yksinäisyyden kokemiseen. Sosiaalilääk Aikak 2006;43:198-206.

21. Bok DC. The Politics of Happiness : What Government Can Learn From the New Research on Well-Being. Princeton: Princeton University Press; 2010. https://doi.org/10.1515/9781400832194

22. Cacioppo JT, Hughes ME, Waite LJ, ym. Loneliness as a Specific Risk Factor for Depressive Symptoms: Cross-Sectional and Longitudinal Analyses. Psychol aging 2006;21(1):140-51. https://doi.org/10.1037/0882-7974.21.1.140

23. Cacioppo J, Patric W. Loneliness: human nature and the need for social connection. New York: W. W. Norton \& Company; 2008.

24. Russell D. UCLA Loneliness Scale Version 3: Reliability, validity, and facor structure. Journal of Personality Assessment 1996;(66):20-40. https://doi.org/10.1207/s15327752jpa6601_2

25. Perlman D, Peplau LA. Loneliness research: A survey of empirical findings. Teoksessa: Peplau LA, Goldston S, toimittajat. Preventing the harmful consequences of severe and persistent loneliness. U.S.: Goverment Printing Office; 1984, 13-46.

26. Tiilikainen E. Yksinäisyys ja elämänkulku. Lectio praecursoria. Gerontologia 2016;30:91-3.

27. Tiilikainen E. Yksinäisyys ja elämänkulku: Laadullinen seurantatutkimus ikääntyvien yksinäisyydestä. Väitöskirja. Helsingin yliopisto, Valtiotieteellinen tiedekunta. Helsinki: Helsingin yliopisto; 2016.

28. Budgeon S. Couple Culture and the Production of Singleness. Sexualities 2008;11:301-25. https://doi.org/10.1177/1363460708089422

29. May V. Why sociology of Personal life? Kirjssa: May, V (toim.) Sociology of Personal Life. UK: Morgan Center for Study of Relationships and Personal Life, University of Manchester; 2011. https://doi.org/10.1007/978-0-230-34421-1

30. Ojala EM, Kontula O. Tarvitseeko minua kukaan? Keski-ikäiset yksineläjät perhekeskeisissä yhteisöissä. Helsinki: Väestöliitto Väestöntutkimuslaitos; 2002.

31. Castrén A-M, Widmer ED. Insiders and outsiders in stepfamilies: Adults' and children's views on family boundaries. Current Sociol 2015;63:35-56. https://doi.org/10.1177/0011392114551650

32. Kontula O. Lemmen paula: Seksuaalinen hyvinvointi parisuhdeonnen avaimena. Perheparometri 2016. Katsauksia Väestöntutkimuslaitos E50/2016. Helsinki: Väestöliitto; 2016.

33. Kontula O. Halu ja intohimo: Tietoa suomalaisesta seksistä. Helsinki: Otava; 2008.

34. Haavio-Mannila E, Kontula O, Kuusi E. Trends in Sexual Life: Measured by national sex surveys in Finland in 1971, 1992 and 1999 and a comparison to a sex survey in St.Petersburg in 1996. Working Papers E 10/2001. The Population Research Institute. Helsinki: The Family Federation of Finland; 2001.

35. Sievers K, Koskelainen O, Leppo K. Suomalaisten sukupuolielämä. Porvoo: Werner Södeström; 1974.

36. Saari J. Huono-osaiset: elämän edellytykset yhteiskunnan pohjalla. Helsinki: Gaudeamus; 2015.

37. Lang TA, Secic M. How to Report Statistics in Medicine: Annotated Guidelines for Authors, Editors, and Reviewers. Philadelphia: American College of Physicians; 1997.

38. Tilastokeskus. Asuntokunnat koon mukaan ja asuntokuntien keskikoko 1960-2014. Luettu 24.2.2017.

http://www.tilastokeskus.fi/til/asas/2014/ asas_2014_2015-05-26_tau_001_fi.html

39. Lumme-Sandt K, Lyyra T-M. Ikääntyvän miehen muuttuva rooli perheessä. Kirjassa: Ojala H, Pietilä I (toim.) Miehistä puhetta: Miehet, ikääntyminen ja vanhenemisen kulttuuriset mallit. Tampere: Tampere University Press; 2013.

40. Tijhuis MA, Jong-Gierveld JD, Feskens EJ, Kromhout D. Changes in and factors related to loneliness in older men: The Zutphen Elderly Study. Age Ageing 1999;28:491-5. https://doi.org/10.1093/ageing/28.5.491

41. Pinquart M. Loneliness in Married, Widowed, Divorced, and Never-Married Older Adults. J Soc Pers Relat 2003;20:31-53. https://doi.org/10.1177/02654075030201002

42. Ketokivi K. The Intimate Couple, Family and the Relational Organization of Close Relationships. Sociology 2012;46:473-89. https://doi.org/10.1177/0038038511422552

43. Loveland Cook CA, Caplan RD, Wolowitz H. Nonwaking Responses to Waking Stressors: Dreams and Nightmares 1. J Appl Soc Psychol 1990;20:199-226. https://doi.org/10.1111/j.1559-1816.1990. tb00407.x

44. Zadra A, Pilon M, Donderi DC. Variety and Intensity of Emotions in Nightmares and Bad Dreams. J Nerv Ment Dis 2006;194:249-54. https://doi.org/10.1097/01. nmd.0000207359.46223.dc

45. Marks NF. Flying Solo at Midlife: Gender, Marital Status, and Psychological Well-Being. J Marriage Fam 1996;58:917-32. https://doi.org/10.2307/353980

46. Julkunen R, Nätti J. Sukupuolijaot taloudessa nousussa. Kirjassa: Piirainen T, Saari J (toim.) Yhteiskunnalliset jaot - 1990-luvun perintö. Helsinki: Gaudeamus; 2002.

47. Kontula O. Yhdessä vai erikseen?: tutkimus suomalaisten parisuhteiden vahvuuksista, ristiriidoista ja erojen syistä. Helsinki: Väestöliitto; 2013.

48. Maksimainen J. Avioliiton pelastamisesta parisuhteen hoitamiseen: muodosta sisältöön. Sosiologia 2014;51:123-137. 
49. Maksimainen J. Parisuhde ja ero: sosiologinen analyysi terapeuttisesta ymmärryksestä.

Väitöskirja. Helsingin yliopisto, Sosiaalitieteiden laitos. Helsinki: Helsingin yliopisto; 2010.

50. Giddens A. Modernity and self-identity: self and society in the late modern age. Cambridge: Polity Press; 1991.

51. Haavio-Mannila E, Kontula O. Seksuaalinen aktiivisuus ikääntyessä. Gerontologia 2007;21:6779.

52. DePaulo B. Singled Out: How Singles Are Stereotyped, Stigmatized, and Ignored, and Still Live Happily Ever After. Reprint edition. New York: St. Martin's Griffin; 2007.

53. Wilkinson, E. Learning to love again: 'Broken families', citizenship and the state promotion of coupledom. Geoforum 2013;49:206-13. https://doi.org/10.1016/j.geoforum.2013.02.012

54. DePaulo B. Singlism: What It Is, Why It Matters, and How to Stop It. Lexington: DoubleDoor Books; 2011.

55. Yksinasuvat Ry. Tutkimuskooste. Luettu 27.8.2016. www.yksinasuvat.fi/tutkittua-tietoa

56. Moisio P. Koettu yksinäisyys demografisten ja sosioekonomisten taustatekijöiden mukaan Suomessa vuosina 1994 ja 2006. Yhteiskuntapolitiikka 2007;72:392.

57. van Gelder BM, Tijhuis M, Kalmijn S, Giampaoli S, Nissinen A, Kromhout D. Marital Status and Living Situation During a 5-Year Period Are Associated With a Subsequent 10-Year Cognitive Decline in Older Men: The FINE Study. J Gerontol Psychol Sci Soc Sci 2006;61B:213-9. https://doi.org/10.1093/geronb/61.4.P213

58. Soons JPM, Liefbroer AC, Kalmijn M. The LongTerm Consequences of Relationship Formation for Subjective Well-Being. J Marriage Fam 2009;71:1254-70.

https://doi.org/10.1111/j.1741-3737.2009.00667.x

Anu Kinnunen

Nuorempi tutkija

Itä-Suomen yliopisto

Yhteiskunta- ja kauppatieteiden tiedekunta

Osmo Kontula

Tutkimusprofessori

Väestöliitto

Väestöntutkimuslaitos 